Penelitian

\title{
Konsentrasi IL-6 Serum terhadap Penyembuhan Luka Pasca Pemasangan Implan Paduan Logam pada Babi (Sus scrofa)
}

\author{
(Serum IL-6 Concentrations in the Wound Healing Process \\ after Metal Based Implant Application in Pig (Sus Scrofa)) \\ Nabila Latifa Hafizsha ${ }^{1^{*}}$, Gunanti ${ }^{2}$, Deni Noviana², Sus Derthi Widhyari ${ }^{2}$ \\ 'Program Pascasarjana Ilmu Biomedis Hewan, Departemen Klinik, Reproduksi, dan Patologi, Fakultas Kedokteran \\ Hewan, Institut Pertanian Bogor \\ ${ }^{2}$ Departemen Klinik, Reproduksi dan Patologi, Fakultas Kedokteran Hewan, Institut Pertanian Bogor \\ *Penulis untuk korespondensi: nabila hafizsha@apps.ipb.ac.id \\ Diterima 7 Oktober 2020, Disetujui 15 Januari 2021
}

\begin{abstract}
ABSTRAK
Penelitian bertujuan untuk mengetahui gambaran konsentrasi IL-6 serum pada fase akut dan kronis selama proses penyembuhan luka pasca pemasangan implan paduan logam pada vesika urinaria babi. Penelitian ini menggunakan 6 ekor babi jantan dan betina, usia 2-3 bulan, dengan bobot badan berkisar 25-30 kg yang dibagi ke dalam dua kelompok implan dan tiga waktu pengamatan. Implan logam yang digunakan adalah $\mathrm{Zn}-0.5 \mathrm{Al}$ sebagai kelompok I dan $\mathrm{ZnMg}(4 \mathrm{x})$ sebagai kelompok II, sedangkan waktu pengamatan dilakukan pada hari ke-0, 14, dan 28. Pemasangan implan dilakukan pada vesika urinaria (VU) menggunakan teknik cystotomi. Pengukuran konsentrasi IL-6 serum menggunakan metode enzyme-linked immunosorbent assay (ELISA). Data dianalasis menggunakan analysis of variance (ANOVA). Hasil penelitian menunjukkan pada hari ke-0, implan Zn-0.5Al dan $\mathrm{ZnMg}(4 \mathrm{x})$ berturut-turut adalah $1.38 \pm 2.40 \mathrm{pg} / \mathrm{mL}$ dan $0.10 \pm 0.17 \mathrm{pg} / \mathrm{mL}$. Konsentrasi IL-6 hari ke-14 pada setiap implan terlihat mengalami penurunan dibandingkan pada hari ke-0, yaitu $0.74 \pm 1.29 \mathrm{pg} / \mathrm{mL}$ dan $0 \mathrm{pg} / \mathrm{mL}$. Selanjutnya hari ke-28 konsentrasi IL-6 kembali mengalami penurunan, yaitu $0.32 \pm 0.35$ $\mathrm{pg} / \mathrm{mL}$ dan $0 \mathrm{pg} / \mathrm{mL}$. Penurunan konsentrasi IL-6 dari fase akut ke fase kronis proses penyembuhan luka pada setiap kelompok implan tidak berbeda signifikan ( $\mathrm{P}>0,05)$. Pemeriksaan serum pada babi (Sus scrofa) terhadap konsentrasi IL6 kelompok perlakuan implan $\mathrm{Zn}-0,5 \mathrm{Al}$ dan $\mathrm{ZnMg}(4 \mathrm{x})$ tidak menunjukkan perbedaan nyata $(\mathrm{P}>0,05)$ pada hari ke-0, 14, dan 28.
\end{abstract}

Kata kunci : babi, implan, IL-6, penyembuhan luka, ZnAl dan ZnMg

\begin{abstract}
The aims of present study was to examine the concentration of serum IL-6 in the acute and chronic phases during wound healing process after metal based implant application on vesica urinary. Six healthy male and female pigs, age range 2-3 months old with $25-30 \mathrm{~kg}$ body weight were divided into two implant groups and three observation time. The metal implant groups used include $\mathrm{Zn}-0.5 \mathrm{Al}$ as group I and $\mathrm{ZnMg}(4 \mathrm{x})$ as group II, while the observation time perfomed on day 0,14 , and 28 . Implantation was performed on vesica urinary using cystotomy techniques. Measurement of IL-6 concentrations is done using enzyme-linked immunosorbent assay (ELISA) methode. Data were analyzed statistically using analysis of variance (ANOVA). The results showed at day o of $\mathrm{Zn}-0.5 \mathrm{Al}$ and $\mathrm{ZnMg}(4 \mathrm{x})$ implant respectively $1.38 \pm 2.40 \mathrm{pg} / \mathrm{mL}$ and $0.10 \pm 0.17 \mathrm{pg} / \mathrm{mL}$. IL-6 concentration of day 14 at each implant was seen decrease compared to day o respectively $0.74 \pm 1,29 \mathrm{pg} / \mathrm{mL}$ and $0 \mathrm{pg} / \mathrm{mL}$. The 28 th day, IL- 6 concentration at each implant was seen decreased respectively $0,32 \pm 0.35 \mathrm{pg} / \mathrm{mL}$ and $0 \mathrm{pg} / \mathrm{mL}$. The results of this study can be concluded that there was a decrease in IL- 6 concentration from acute phase to chronic phase in wound healing process in each implant group does not differ significantly $(\mathrm{P}>0.05)$.
\end{abstract}

Keywords: pig, implant, IL-6, wound healing, ZnAl and ZnMg 


\section{PENDAHULUAN}

Babi merupakan hewan model yang telah banyak digunakan pada penelitian di berbagai negara. Babi secara umum memiliki kemiripan anatomi dan fisiologis dengan manusia, salah satunya dalam proses penyembuhan luka pada kulit. Babi memiliki kemiripan kulit dengan manusia seperti epidermis yang relatif tebal, jaringan tanduk yang berbeda, papila dermal, serabut elastis yang padat di bagian dermis, dan waktu pergantian epidemis pada babi serupa dengan manusia yaitu sekitar 30 hari (Seaton et al., 2015).

Penyembuhan luka merupakan sebuah respon morfogenetik terhadap cedera yang bertujuan untuk mengembalikan fungsi fisiologis dan anatomis. Proses biologis penyembuhan luka terdiri dari empat fase, yaitu hemostasis, inflamasi, proliferasi, dan remodeling yang diatur oleh berbagai sel, sitokin, dan faktor pertumbuhan (Tsai et al., 2019). Interleukin-6 (IL-6) merupakan sebuah mitogen dan stimulator fibroproliferasi yang kuat serta akumulasinya di dalam luka mengarah ke fase proliperatif penyembuhan luka atau dengan kata lain IL-6 pada penyembuhan luka merupakan sitokin pleiotropik yang terlibat dalam pertumbuhan dan diferensiasi berbagai jenis sel, meskipun demikian konsentrasi IL-6 yang rendah memiliki peran penting dalam mempercepat peradangan, sehingga membantu mempercepat penyembuhan luka khususnya pada tahap awal (Seaton et al., 2015).

Penggunaan biomaterial sebagai implan dalam dunia medis telah berkembang secara dramatis selama beberapa dekade terakhir, bukan hanya digunakan pada ortopedi dan kardiovaskular, tetapi juga urologi. Implan pada vesika urinaria digunakan sebagai teknik rekonstruktif berbagai keadaan yang abnormal, seperti kanker, disfungsi neurogenik, overaktif destrusor, inflamasi kronis, trauma, cedera iatrogenik, urolithiasis, dan sebagainya (Elsawy \& Achala, 2017). Sheta et al. (2014) menambahkan penggunaan implan tersebut bertujuan untuk menjaga integritas dinding, memperbesar kapasitas, dan mengurangi tekanan intravesikal pada vesika urinaria.

Penggunaan material implan menimbulkan respon imun yang merupakan faktor penting dari aspek biokompatibilitas atau sering disebut imunostimulasi. Imunostimulasi berkaitan dengan komplek imunoregulator yang dapat meningkatkan sistem imun dengan efek klinis, salah satunya adalah inflamasi. Efek tersebut melibatkan reaksi imun nonspesifik, yaitu molekul sinyal seperti sitokin yang disekresikan dari sel imun pada lokasi pemasangan material, kemudian akan dikenalkan pada sel imun melalui interaksi pada permukaan material (Franz et al., 2011). Hal ini sesuai dengan pendapat Baki (2014) bahwa sitokin merupakan mediator esensial untuk menilai respon imun terhadap infeksi dan berperan terhadap jalur utama respon inflamasi, yaitu memiliki efek mediasi dan mempertahankan respon inflamasi, serta dapat menginisiasi perubahan sistemik yang terjadi.

Beberapa penelitian mengenai konsentrasi IL- 6 pada penyembuhan luka kulit sudah dijelaskan dengan baik pada mencit (Gallucci et al., 2000; Lin et al., 2003), namun jarang ditemukan penjelasan ilmiah pada penyembuhan luka pasca pemasangan implan di vesika urinaria babi. Berdasarkan latar belakang di atas, maka penelitian ini dilakukan untuk mengkaji konsentrasi IL- 6 serum babi pada proses penyembuhan luka pada kulit yang mendapatkan perlakuan implantasi berbahan paduan logam $\mathrm{Zn}$ $0,5 \mathrm{Al}$, dan $\mathrm{ZnMg}(4 \mathrm{x})$ di vesika urinaria pada hari ke 0,14 , dan 28.

\section{BAHAN DAN METODE}

\section{Ethical Approval}

Semua prosedur dalam penelitian ini telah mendapat izin dari Komisi Etik Hewan IPB dengan nomor 152/KEH/SKE/X/2019.

\section{Aklimatisasi Hewan}

Penilitian ini menggunakan 6 ekor babi, baik jantan maupun betina, berusia 2-3 bulan dengan bobot badan $25-30 \mathrm{~kg}$, dan secara klinis dinyatakan sehat. Semua babi diaklimatisasi selama 14 hari sebelum diberi perlakuan. Tujuan aklimatisasi agar hewan beradaptasi dengan lingkungan selama penelitian berlangsung dan memiliki status kesehatan yang sama. Babi diberi pakan dua kali sehari dan air minum secara ad-libitum, kemudian diberikan anthelmintik ivermectin dan clorsulon (Ivomec ${ }^{\circledR}$ super, Merial, Lyon-France) dengan dosis $1 \mathrm{ml} / 33 \mathrm{~kg}$ berat badan secara injeksi dan antibiotik sulfadiazine dan trimetroprim (Colibact ${ }^{\circledR}$ bolus, Sanbe Farma, Bandung-Indonesia) dengan dosis 1 bolus yang dicampurkan ke dalam pakan pada hari ke 1, 4, dan 7. Aklimatisasi hewan dilakukan di Kandang Hewan Unit Pengelolaan Hewan Laboratorium (UPHL), Fakultas Kedokteran Hewan IPB.

\section{Pemasangan Implan}

Babi dibagi menjadi dua kelompok implan, yaitu $\mathrm{Zn}-0.5 \mathrm{Al}$ dan $\mathrm{ZnMg}(4 \mathrm{x})$ yang masing-masing terdiri 
dari 3 ekor babi. Hewan dipuasakan makan selama 12 jam dan puasa minum 4 jam sebelum diberi perlakuan, kemudian diberi anestesi kombinasi zolazepam-tiletamin-xilazin $250 \mathrm{mg}$ (Zoletile ${ }^{\circledR}$, Virbac, Nice-France) dosis $7 \mathrm{mg} / \mathrm{kg}$ BB dengan xylazin $20 \mathrm{mg}$ (llium Xylazine-100 ${ }^{\circledR}$, Ilium, Australia) dosis 0,5 $\mathrm{mg} / \mathrm{kg}$ BB. Babi yang telah teranestesi kemudian dilakukan pemasangan implan pada vesika urinaria (VU) menggunakan teknik cystotomi. Babi diposisikan dorsal recumbency kemudian VU dikosongkan terlebih dahulu dengan cytosintesis menggunakan jarum 22-Gauge sebelum dilakukan cystotomi. Tahap selanjutnya dilakukan sayatan lurus pada kulit dan jaringan subkutan di caudal umbilicus sejajar linea alba kemudian dilakukan penyayatan di muskulus rektus abdominis sampai ruang abdominal terbuka. Setelah itu dilakukan pencarian VU dan dikeluarkan dari rongga abdomen menggunakan kasa steril yang sebelumnya sudah diberikan larutan saline. Langkah berikutnya adalah penyayatan di serosa, kemudian implan dilekatkan pada mukosa bagian dorsal VU, setelah pemasangan implant VU dijahit dengan pola lambert menggunakan benang polydiaxanone (PDO) (2/o, Safil ${ }^{\circledR}$, Indonesia) pada lapisan serosa, sedangkan jahitan pada muskulus rektus abdominis menggunakan pola simple continuous dengan benang polyglycolic acid (PGA) (2/o, Safil ${ }^{\circledR}$, Indonesia).

Kulit dan subkutis dijahit dengan pola simple interrupted menggunakan benang silk ( $3 / 0$, GEA) dan luka jahitan diobservasi pada hari ke 14 dan 28 . Perlakuan pada babi kontrol hanya dilakukan sayatan kulit hingga $\mathrm{VU}$ dengan pola jahitan yang sama tanpa dilakukan pemasangan implan. Perlakuan pascabedah, babi diberi terapi seperti antibiotik berupa marbofloxacin (Marbocyl® $2 \%$, Vetoquinol, France) dosis $1 \mathrm{~mL} / 10 \mathrm{kgBB}$ selama 7 hari dan tolfenamic acid (Tolfedine ${ }^{\circledR C S}$, Vetoquinol, France) sebagai antiinflamasi dosis $0,1 \mathrm{ml} / \mathrm{kgBB}$ selama 3 hari. Babi dipelihara di kandang individual untuk diobservasi pemulihannya. Perawatan luka pasca bedah dilakukan dengan pemberian salep gentamisin satu kali setiap dilakukan observasi luka. Proses pemasangan implan dilaksanakan di Rumah Sakit Hewan Pendidikan, Fakultas Kedokteran Hewan IPB.

\section{Uji Konsentrasi IL-6}

Pengambilan sampel darah dilakukan pada hari ke 0 , 14, dan 28. Pengambilan darah hari ke-o dilakukan pada menit ke-60 setelah pemasangan implan. Darah diambil melalui vena auricularis, kemudian dimasukkan ke plain vaccutainer untuk pengujian kadar IL-6 dan dibiarkan beku sebelum dilakukan sentrifus selama 15 menit dengan kecepatan 3000 revolutions per minute (rpm) untuk mendapatkan serum. Serum yang diperoleh kemudian diuji konsentrasi IL-6 dengan menggunakan metode enzyme-linked immunosorbent assay (ELISA) mengikuti aturan yang telah ditetapkan oleh perusahaan The Termo Scientific $^{\top \mathrm{M}}$ selaku produsen alat yang digunakan : semua reagen, sampel, dan standar disiapkan sesuai instruksi yang tertera kemudian $100 \mu \mathrm{L}$ larutan standar dan sampel dimasukkan ke dalam Wells lalu ditutup dan diinkubasi pada suhu ruangan selama 2,5 jam. Penutup sealer plate dibuka kemudian plate dicuci dengan wash buffer sebanyak 4 kali, selanjutnya $100 \mu \mathrm{L}$ Biotyninylated antibody ditambahkan ke dalam wells, lalu ditutup dan diinkubasi pada suhu ruangan selama 60 menit. Plate dicuci dengan wash buffer sebanyak 4 kali. $100 \mu \mathrm{L}$ reagen Streptavidin HRP dimasukkan ke seluruh well, ditutup, dan diinkubasi pada suhu ruangan selama 45 menit. Plate dicuci kembali dengan wash buffer sebanyak 4 kali. $100 \mu \mathrm{L}$ substrat TMB ditambahkan ke seluruh well, lalu plate ditutup dan diinkubasi pada tempat gelap dengan suhu ruangan selama 30 menit kemudian ditambahkan $50 \mu \mathrm{L}$ stop solution ke seluruh well.

Tahap terakhir adalah hasil absorbansi diukur dan dihitung menggunakan ELISA plate reader dengan panjang gelombang $450 \mathrm{~nm}$, sehingga didapatkan grafik dan persamaan garis (equattion/coefficient) yang diperoleh dari kurva standar kemudian digunakan untuk menghitung nilai konsentrasi masing-masing sampel. Pengujian konsentrasi IL-6 dilaksanakan di Indonesian Medical Education and Research Institute Fakultas Kedokteran Universitas Indonesia (IMERI FKUI).

\section{Penilaian Makroskopis Luka}

Pengamatan luka jahitan kulit dilakukan secara makroskopis, kemudian dilakukan penilaian terhadap gambaran klinis penyembuhan luka setiap kelompok implan pada babi (Sus scrofa). Penilaian makroskopis yang dilakukan sebagai berikut:

a. Respon inflamasi diobservasi pada hari ke-o (menit ke-60), 14, dan 28 dengan kategori skor, yaitu: 3 (iskemia dan bengkak), 2 (hiperemia disertai bengkak), 1 (tidak ada respon inflamasi). Perubahan warna kulit yang diamati berdasarkan kategori merah kehitaman/nekrosis, iskemia, hiperemia, atau sama dengan warna kulit sekitar luka (Erwin et al., 2016)

b. Tanda-tanda infeksi seperti ada atau tidaknya akumulasi cairan purulen diobservasi pada hari ke-0, 14, dan 28 dengan kategori skor, yaitu: 3 
(banyak cairan purulen), 2 (sedikit cairan purulen), 1 (tidak ada cairan purulen/tidak infeksi)

c. Waktu penyembuhan luka diobservasi pada setiap kelompok implan dengan kategori skor, yaitu: 3 ( $>14$ hari), 2 (7-14 hari), 1 ( $<7$ hari) (Nagaoka et al. 2000).

\section{Analisis Data}

Data kuantitatif dianalisis secara statistik menggunakan metode analysis of variance (ANOVA) menggunakan software SPSS 20, jika terdapat perbedaan nyata akan dilanjutkan dengan Duncan pada selang kepercayaan 95\%. Data disajikan dalam bentuk rataan dengan standar deviasi dan dijelaskan secara deskriptif naratif.

\section{HASIL}

\section{Konsentrasi IL-6}

Pemeriksaan serum pada babi (Sus scrofa) menghasilkan gambaran rata-rata konsentrasi IL-6 yang tidak menunjukkan perbedaan nyata pada kelompok perlakuan implan $\mathrm{Zn}-0.5 \mathrm{Al}$ dan $\mathrm{ZnMg}(4 \mathrm{x})$ ataupun kontrol di hari ke-0, 14, dan 28 ( $P>0,05)$. Rata-rata konsentrasi IL-6 dapat dilihat pada Tabel 1. Konsentrasi IL-6 hari ke-o pada implan Zn-0.5Al dan $\mathrm{ZnMg}(4 \mathrm{x})$ berturut-turut adalah $1.38 \pm 2.40 \mathrm{pg} / \mathrm{mL}$ dan $0.10 \pm 0.17 \mathrm{pg} / \mathrm{mL}$. Hari ke-14 konsentrasi IL-6 pada implan $\mathrm{Zn}-0.5 \mathrm{Al}$ dan $\mathrm{ZnMg}(4 \mathrm{x})$ terlihat mengalami penurunan dibandingkan pada hari ke-o meskipun tidak signifikan, yaitu $0.74 \pm 1.29 \mathrm{pg} / \mathrm{mL}$ dan $0 \mathrm{pg} / \mathrm{mL}$, dan hari ke-28 konsentrasi IL- 6 kembali mengalami penurunan, yaitu $0.32 \pm 0.35$ dan $0 \quad \mathrm{pg} / \mathrm{mL}$. Perbandingan hasil rata-rata konsentrasi IL-6 antara kedua implan yaitu $\mathrm{Zn}-0.5 \mathrm{Al}$ dan $\mathrm{ZnMg}(4 \mathrm{x})$ menunjukkan kelompok $\mathrm{ZnMg}(4 \mathrm{x})$ memiliki penurunan konsentrasi IL-6 yang lebih baik dibandingkan dengan kelompok Zn-0.5Al (Gambar 1).

\section{Penyembuhan Luka}

Pengamatan reaksi inflamasi dilakukan dengan melihat tanda inflamasi seperti kemerahan, pem-

Tabel 1 Rata-rata konsentrasi IL-6 (pg/mL) babi (Sus scrofa) yang diimplan paduan logam Zn-0.5Al, ZnMg(4x) pada vesika urinaria, dan kontrol

\begin{tabular}{|c|c|c|c|}
\hline \multirow{2}{*}{$\begin{array}{c}\text { Waktu } \\
\text { Pengamatan } \\
\text { (Hari ke-) }\end{array}$} & \multicolumn{3}{|c|}{ Kelompok Implan } \\
\hline & $\mathrm{Zn}-0,5 \mathrm{Al}$ & ZnMg (4x) & Kontrol \\
\hline 0 & $1,38 \pm 2,40^{a}$ & $0,10 \pm 0,17^{a}$ & 0 \\
\hline 14 & $0,74 \pm 1,29^{a}$ & $0^{a}$ & 0 \\
\hline 28 & $0,32 \pm 0,35^{\mathrm{a}}$ & $0^{a}$ & 0 \\
\hline
\end{tabular}

Data disajikan dalam bentuk rataan dengan standar deviasi $(\bar{x} \pm S D)$. Huruf superscript yang sama pada baris dan kolom yang berbeda menunjukkan perbedaan yang tidak nyata $(P>0,05)$.

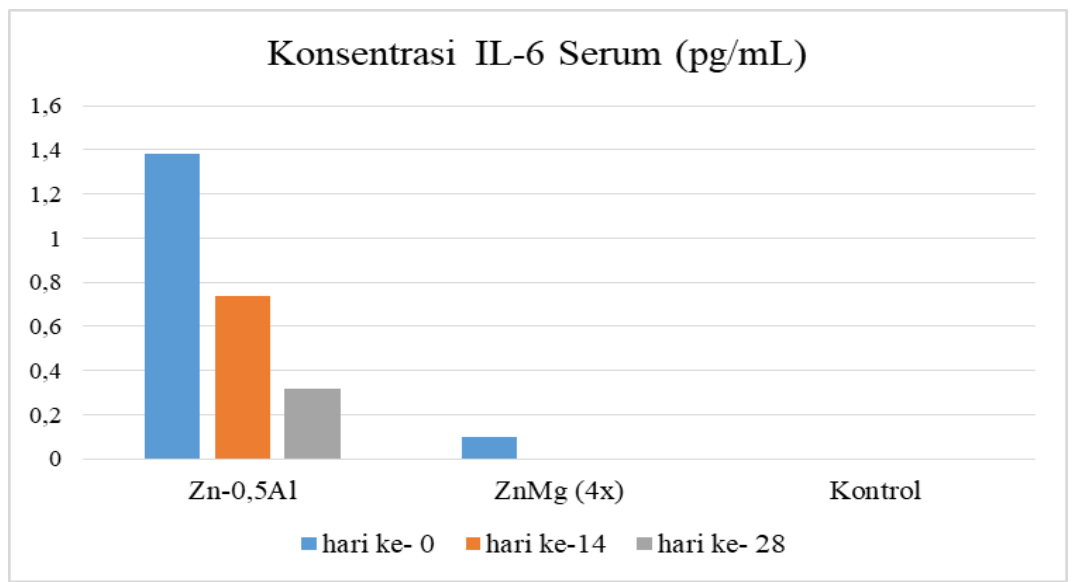

Gambar 1 Grafik konsentrasi IL-6 serum (pg/mL) pada babi (Sus scrofa) yang diimplan paduan logam $\mathrm{Zn}-0.5 \mathrm{Al}, \mathrm{ZnMg}(4 \mathrm{x})$ pada vesika urinaria, dan kontrol 
bengkakan, dan panas pada daerah luka. Berdasarkan rata-rata skor kelompok implan Zn$0.5 \mathrm{Al}$ dan $\mathrm{ZnMg}(4 \mathrm{x})$ pada hari ke-o yang disajikan pada Tabel 2 menunjukkan hasil yang sama dengan skoring 2,00 $\pm 0,00$ (kemerahan dan pembengkakan), sedangkan hari ke-14 dan 28 tidak menunjukkan tanda inflamasi $(1,00 \pm 0,00)$.

Pengamatan infeksi pada penelitian ini dilakukan dengan melihat ada atau tidaknya akumulasi cairan purulen pada daerah luka. Rata-rata skor kelompok implan Zn-0.5Al dan $\mathrm{ZnMg}(4 \mathrm{x})$ pada hari ke-0, 14, dan 28 yang disajikan pada Tabel 3 menunjukkan hasil skoring yang sama, yaitu $1,00 \pm 0,00$ atau dengan kata lain tidak terjadi infeksi pada luka di setiap waktu pengamatan.

Berdasarkan hasil yang disajikan Tabel 4, ratarata waktu penyembuhan luka setiap babi pada kedua kelompok implan terjadi antara hari ke-7 hingga 14 (2.33 \pm 0.57$)$. Luka pada hari ke-o menunjukkan adanya gejalanya inflamasi seperti kemerahan dan bengkak, selain itu jaringan kulit masih terlihat basah dan renggang. Respon inflamasi pada luka seperti kemerahan dan bengkak telah menghilang di hari ke-14 dan jaringan kulit sudah terlihat mengering dan menyatu, selanjutnya pada hari ke-28 jaringan kulit yang mengalami perlukaan telah kembali normal. Gambaran luka jahitan pada kedua kelompok implan dapat dilihat pada Gambar 2.

\section{PEMBAHASAN}

Konsentrasi IL- 6 serum babi yang dihasilkan pada penelitian ini berada pada kisaran normal. Hal ini didukung oleh Kilpadi et al. (2006) bahwa konsentrasi normal IL- 6 dalam darah adalah sangat rendah dan dapat tidak terdeteksi atau hanya terdeteksi saat mengalami trauma dan adanya infeksi. IL-6 pada hari ke-o dapat terdeteksi dikarenakan IL-6 merupakan mediator inflamasi yang konsisten muncul setelah terjadi pembedahan, trauma akut, dan infeksi (Jung et al., 2013). Han (2016) menambahkan hanya diperlukan beberapa jam setelah adanya luka, beberapa faktor pertumbuhan dan sitokin proinflamasi dilepaskan ke area luka seperti IL-1, TNF- $\alpha$, dan IL- 6 untuk mengaktifkan netrofil bermigrasi melalui sel endotel ke dalam dinding kapiler darah menuju daerah luka, sehingga terjadi deposit matriks fibrin sebagai awal proses penutupan luka.

Kehadiran IL-6 pada hari ke-14 dalam proses penyembuhan luka disebabkan pada hari ke 7-14 adalah fase poliferasi, yaitu fase yang masih memerlukan IL-6 sebagai reseptor untuk merangsang keratinosit yang berperan dalam penyembuhan luka (Macleod \& Mansbridge, 2015). Fase proliferasi terjadi sekitar hari ke 4-14 setelah terjadi luka yang ditandai dengan pembentukan jaringan granulasi. Epitelisasi juga terjadi selama fase ini sebagai keratinosit

Tabel 2 Rata-rata skor penilaian reaksi inflamasi luka jahitan kulit hari ke-o, 14, dan 28 pada babi (Sus scrofa) yang diimplan paduan logam $\mathrm{Zn}-0.5 \mathrm{Al}$ dan $\mathrm{ZnMg}(4 \mathrm{x})$ pada vesika urinaria

\begin{tabular}{ccc}
\hline $\begin{array}{c}\text { Waktu Pengamatan } \\
\text { (Hari ke-) }\end{array}$ & \multicolumn{2}{c}{ Jenis Implan dan Skor } \\
\cline { 2 - 3 } & Zn-0,5Al & ZnMg(4x) \\
\hline 0 & $2.0 \pm 0.0$ & $2.0 \pm 0.0$ \\
\hline 14 & $1.0 \pm 0.0$ & $1.0 \pm 0.0$ \\
\hline 28 & $1.0 \pm 0.0$ & $1.0 \pm 0.0$ \\
\hline
\end{tabular}

Keterangan: skor 1 di sekitar luka tidak bengkak, tidak panas, dan tidak merah; skor 2 di sekitar luka bengkak dan kemerahan; dan skor 3 di sekitar luka ada bengkak, panas, dan kemerahan

Tabel 3 Rataan skor penilaian reaksi infeksi pada luka jahitan kulit hari ke-0, 14, dan 28 pada babi (Sus scrofa) yang diimplan paduan logam $\mathrm{Zn}-0.5 \mathrm{Al}$ dan $\mathrm{ZnMg}(4 \mathrm{x})$ pada vesika urinaria Waktu Pengamatan Jenis Implan dan Skor

\begin{tabular}{ccc}
$\begin{array}{c}\text { Waktu Pengamatan } \\
\text { (Hari ke-) }\end{array}$ & \multicolumn{2}{c}{ Jenis Implan dan Skor } \\
\cline { 2 - 3 } & Zn-0,5Al & $\mathrm{ZnMg}(4 \mathrm{x})$ \\
\hline 0 & $1.0 \pm 0.0$ & $1.0 \pm 0.0$ \\
\hline 14 & $1.0 \pm 0.0$ & $1.0 \pm 0.0$ \\
\hline 28 & $1.0 \pm 0.0$ & $1.0 \pm 0.0$ \\
\hline
\end{tabular}

Keterangan: skor 1 tidak terjadi infeksi pada luka; skor 2 ada sedikit cairan purulen pada luka; dan skor 3 banyak cairan purulen dan berbau pada luka. 
26 | Hafizsha et al.

Tabel 4 Rata-rata skor penilaian waktu penyembuhan luka jahitan kulit pada babi (Sus scrofa) yang diimplan paduan logam $\mathrm{Zn}-0.5 \mathrm{Al}$ dan $\mathrm{ZnMg}(4 \mathrm{x})$ pada vesika urinaria

\begin{tabular}{ccc}
\hline Jenis Implan & Zn-0,5Al & ZnMg(4x) \\
\hline Skor & $2.33 \pm 0.57$ & $2.33 \pm 0.57$ \\
\hline
\end{tabular}

Keterangan: skor 1 waktu penyembuhan kurang dari 7 hari; skor 2 waktu penyembuhan antara 7-14 hari; dan skor 3 waktu penyembuhan lebih dari 14 hari

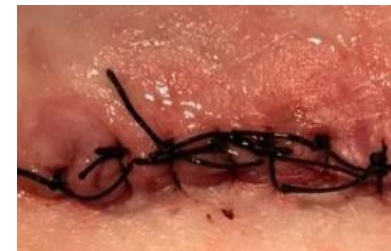

A0

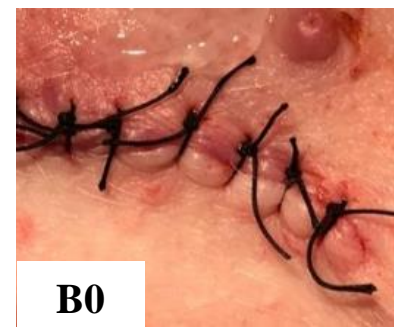

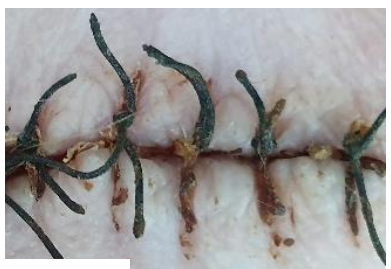

A14

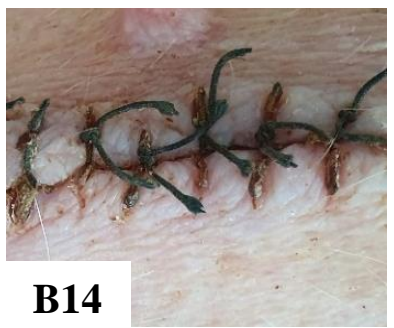

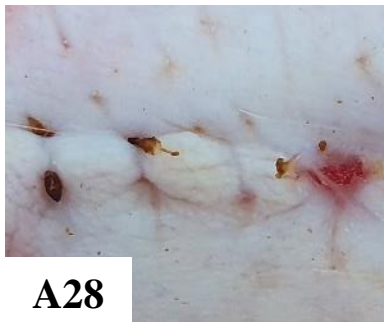

A28

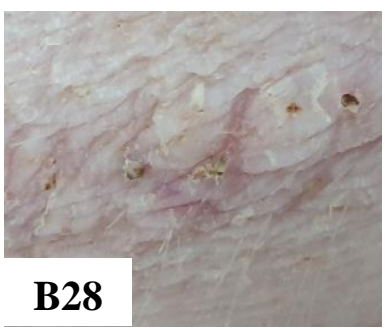

Gambar 2 Gambaran klinis penyembuhan luka jahitan kulit pada babi (Sus scrofa) yang diimplan paduan logam $\mathrm{Zn}-0.5 \mathrm{Al}$ dan $\mathrm{ZnMg}(4 \mathrm{x})$ pada vesika urinaria. Kelompok $\mathrm{Zn-0.5Al} \mathrm{(Ao:} \mathrm{luka} \mathrm{jahitan} \mathrm{pada} \mathrm{hari} \mathrm{ke-}$ 0, A14: luka jahitan pada hari ke-14, dan A28: luka jahitan pada hari ke-28), kelompok ZnMg(4x) (Bo: luka jahitan pada hari ke-o, B14: luka jahitan pada hari ke-14, dan B28: luka jahitan pada hari ke-28)

yang bermigrasi ke daerah luka (Han, 2016). Hasil penelitian ini sejalan dengan penelitian Kuhn et al. (2014) bahwa IL-6 sangat diperlukan dalam proses penyembuhan luka pada fase proliferasi untuk merangsang proliferasi epitel, meskipun demikian penurunan konsentrasi IL- 6 terbukti berhasil mengendalikan inflamasi yang sifatnya sistemik.

Konsentrasi IL- 6 pada hari ke-28 mengalami penurunan bahkan kelompok $\mathrm{ZnMg}(4 \mathrm{x})$ sudah kembali normal dapat dikarenakan kehadiran IL-6 sudah tidak diperlukan. Hasil penelitian ini sesuai dengan pendapat Thalib (2017) bahwa setelah hari ke-14 dengan berakhirnya fase proliferasi, konsentrasi IL-6 seharusnya mengalami penurunan karena tidak diperlukan pada fase selanjutnya yaitu fase remodeling. Penurunan kadar IL-6 pada fase remodeling menjadi tanda bahwa tidak terjadi infeksi atau inflamasi kronis pada luka, sehingga penyembuhan luka dapat berlangsung dengan baik.

Gonzalez et al. (2016) menambahkan bahwa selama fase remodeling mayoritas pembuluh darah yang terbentuk, fibroblas, sitokin, dan sel inflamasi menghilang dari daerah luka akibat proses emigrasi, apoptosis, dan mekanisme kematian sel lainnya yang tidak diketahui. Peningkatan konsentrasi IL-6 yang berlebihan merupakan sinyal respon imun terjadinya inflamasi kronis pada luka, infeksi, kanker, dan penyakit autoimun (Naseem et al., 2016).

Berdasarkan hasil penelitian yang dilakukan menunjukkan konsentrasi IL-6 kedua implan cenderung mengalami penurunan, hal ini menjelaskan bahwa penggunaan kedua implan tidak bersifat imunostimulasi dan relatif aman digunakan dalam jangka waktu lama pada vesika urinaria. Menurut Levy et al. (2017) magnesium (Mg) merupakan elemen yang menjadi pilihan utama sebagai paduan zinc (Zn). Gu dan Zheng (2010) menambahkan bahwa paduan $\mathrm{ZnMg}$ memiliki laju korosi dan menghasilkan gas hidrogen yang lebih rendah jika dibandingkan dengan biner lainnya. 
Mineral Zn juga dapat dipadukan dengan elemen lain yang juga dapat menggantikan sifat paduan $\mathrm{Mg}$, antara lain litium ( $\mathrm{Li}$ ) dan aluminium (Al), namun kedua elemen memiliki potensial toksisitas yang lebih tinggi dibandingkan $\mathrm{Mg}$. Hal ini menyebabkan penambahan dua elemen sebagai paduan, maka persentase berat yang digunakan harus dibatasi. Selain itu, laju degradasi dari paduan $\mathrm{Zn}$ yang mengandung unsur ini harus sesuai dengan toleransi atau kisaran dosis efektif dalam tubuh. Paduan $\mathrm{Zn}$ Mg dan Zn - Al pada konsentrasi kurang dari satu persen sudah dapat meningkatkan sifat mekanik dan daktilitas yang memadai, sehingga tidak diperlukan penggunaan jumlah yang berlebihan dari elemen paduan lain yang berpotensi beracun (Levy et al., 2017).

\section{Penyembuhan Luka}

Penyembuhan luka berlangsung dalam 3 fase utama, yaitu fase inflamasi, fase proliferasi, dan fase maturasi atau remodeling. Tingginya konsentrasi IL6 pada hari ke-o setelah perlukaan berbanding lurus dengan respon inflamasi yang ditunjukkan pada hasil pengamatan makroskopis. Hal ini disebabkan kerusakan jaringan memicu pelepasan sitokin yang salah satunya adalah IL-6 sebagai respon awal untuk memperantarai serangkaian proses inflamasi, sehingga dapat menimbulkan gejala inflamasi sebagai bentuk respon imun (Karnen et al., 2012).

Hasil skoring reaksi inflamasi pada penelitian ini sesuai dengan Li et al. (2007) bahwa reaksi inflamasi berlangsung selama 24-48 jam pertama dan dapat menetap hingga 2 minggu pasca perlukaan. Kemerahan atau rubor yang terjadi disebabkan pada fase inflamasi arteriola yang menyuplai darah ke daerah luka mengalami vasodilatasi, sehingga banyak darah yang mengalir ke mikrosirkulasi lokal akibatnya kapiler merenggang dan terisi penuh dengan darah. Kondisi tersebut secara klinis sering disebut dengan kongesti atau hiperemi, sedangkan pembengkakan atau tumor disebabkan vasodilatasi arteriol dan aliran darah yang bertambah akan meningkatkan tekanan hidrostatik intravaskular dan pergerakan cairan dari kapiler. Hilangnya cairan kaya protein ke dalam ruang perivaskular menurunkan tekanan osmotik intravaskular dan meningkatkan tekanan osmotik cairan interstisial, keadaan ini akan menyebabkan terlihatnya edema pada daerah luka (Campbell, 2010).

Hasil skoring waktu penyembuhan luka pada penelitian ini menunjukkan penyembuhan berlangsung relatif cepat, hasil ini sesuai dengan Dada dan
Ananta (2017) bahwa penyembuhan luka jahitan pada babi dapat berlangsung relatif cepat jika ditangani dengan baik. Lostapa et al., (2016) menambahkan penanganan luka yang tepat dapat meningkatkan penyembuhan, mencegah kerusakan kulit lebih lanjut, dan mengurangi resiko terjadinya infeksi.

Perawatan luka yang diberikan pada penelitian ini adalah pemberian antibiotik sistemik berupa marbofloxacin yang dikombinasikan dengan salep gentamisin sebagai antibiotik topikal. Hal ini sesuai dengan Daeschlein (2013) bahwa pemberian antibiotik topikal secara tunggal kurang efektif dalam membunuh bakteri pada luka insisi, sehingga diperlukan kombinasi dengan antibiotik sistemik untuk mengurangi resiko infeksi. Kegunaan pemberian antibiotik secara topikal juga dapat membantu mempercepat epitelisasi jaringan pada kulit.

Pengamatan infeksi dilakukan dengan melihat ada atau tidaknya akumulasi cairan purulen pada daerah luka. Berdasarkan skoring kelompok implan $\mathrm{Zn}-0.5 \mathrm{Al}$ dan $\mathrm{ZnMg}(4 \mathrm{x})$ pada hari ke-0, 14, dan 28 menunjukkan tidak terjadi infeksi pada luka di setiap waktu pengamatan. Hal ini dapat dikarenakan tindakan bedah dilakukan secara aseptis dan diberikan penanganan luka secara tepat. Hasil ini sesuai dengan Arisanty (2013) bahwa luka infeksi adalah luka dengan replikasi mikroorganisme lebih dari 10 pangkat lima per gram jaringan akibat penanganan luka yang tidak tepat yang ditandai dengan adanya cairan purulen di sekitar luka, pembengkakan, berbau, dan perubahan warna kulit pada luka. Wilkinson et al. (2016) menambahkan invasi bakteri pada luka insisi dapat terjadi pada saat dilakukan pembedahan atau setelah pembedahan, sehingga diperlukan penanganan yang tepat untuk meminimalisir resiko infeksi. Resiko infeksi pada luka insisi sendiri dapat terjadi pada hari ke-5 hingga 7 hari pasca bedah.

Hasil penelitian ini dapat disimpulkan bahwa terjadi penurunan konsentrasi IL- 6 dari fase akut ke fase kronis dalam proses penyembuhan luka setiap kelompok implan $\mathrm{Zn}-0.5 \mathrm{Al}$ dan $\mathrm{ZnMg}(4 \mathrm{x})$ pada vesika urinaria babi (Sus scrofa) serta penyembuhan luka jahitan kulit setiap kelompok implan berlangsung dengan baik dan tidak terjadi infeksi pada luka.

\section{UCAPAN TERIMA KASIH}

Penulis ucapkan terima kasih kepada Kementerian Riset, Teknologi, dan Pendidikan Tinggi atas dukungan dana melalui hibah Kerjasama Luar Negeri (KLN) dengan nomor 
kontrak: 3/E1/KP.PTNBH/2019. Penulis mengucapkan terima kasih kepada Prof Hendra Hermawan dari Laval University atas bantuan karakterisasi material. Ucapan terima kasih juga diberikan kepada Dr Deni Shidqi dari LIPI atas bantuan dalam pembentukan dan potongan material implan di laboratorium fisika LIPI serta semua pihak yang telah membantu Penulis, sehingga penilitian ini dapat terlaksana dengan baik. Penulis menyatakan tidak ada konflik kepentingan dengan pihak-pihak yang terkait dalam penelitian ini.

"Penulis menyatakan tidak ada konflik kepentingan dengan pihak-pihak yang terkait dalam penelitian ini".

\section{DAFTAR PUSTAKA}

Arisanty IP. 2013. Manajemen Perawatan Luka: Konsep Dasar. EGC. Jakarta.

Baki ED. 2014. Effects of anesthetic choice on inflammatory response in cardiac surgery. Cellular Signalling 4:1-5.

Campbell J. 2010. Wounds and Healing. www.campbellteaching.co.uk/sample/pdf.

Download: June 20, 2020.

Dada IKA, Ananta MG. 2017. Studi kasus: penanganan hernia umbilikalis pada babi Duroc. Indonesia Medicus Veterinus 6(2):169-180.

Daeschlein G. 2013. Antimicrobial and antiseptic strategies in wound management. International Wound Journal 10(1):9-14.

Elsawy MM, Achala DM. 2017. Biofabrication and biomaterials for urinary tract reconstruction. Reasearch and Reports in Urology 9:79-92.

Erwin, Gunanti, Handharyani E, Noviana D. 2016. Subjective and objective observation of skin graft recovery on indonesian local cat with different periods of transplantation time. Veterinary World 9(5):481-486.

Franz S, Rammelt S, Scharnweber D, Simon JC. 2011. Immune responses to implants - a review of the implications for the design of immunomodulatory biomaterials. Biomaterials 32(28):6692-6709.

Gallucci RM, Simeonova PP, Matheson JM, Kommineni C, Guriel JL, Sugawara T, Luster MI. 2000. Impaired cutaneous wound healing in interleukin-6 deficient and immunosuppressed mice. The FASEB Journal 14:2525-2531.
Gonzalez ACO, Andrade ZA, Costa TF, Medrado AR. 2016. Wound healing. Anais Brasileiros de Dermatologia 91(5):614-620.

$\mathrm{Gu}$ XN, Zheng YF. 2010. A review on magnesium alloys as biodegradable materials. Fronters of Material Science 4: 111-115.

Han SK. 2016. Inovations and Advances in Wound Healing. $2^{\text {th }}$ Ed. Springer-Verlag Berlin Heidelberg. New York.

Jung Y, Swon D, Kwon S, Han K. 2013. Experimental pig model of clinically relevant wound healing delay by instrinsic factors. International Wound Journal 10:295-305.

Karnen G, Baratawidjaya, Iris R. 2012. Imunologi Dasar. Edisi ke-10. Universitas Indonesia. Jakarta.

Kilpadi DV, Bower CE, Reade CC, Robinson PJ, Sun YS, Zeri R, Nifong LW, Wooden WA. 2006. Effect of vacum assisted closure therapy on early systemic cytokine levels in a swine model. Wound Repair and Regeneration 14:210-215.

Kuhn KA, Manieri NA, Liu TC, Stappenbeck TS. 2014. IL-6 stimulates intestinal ephitelial proliferation and repair after injury. Plos one 9(12): 114-195.

Levy GK, Goldman J, Aghion E. 2017. The prospect of zinc as a structural material for biodegradable implants. Review Metals 7:402.

Li J, Juan C, Kirsner R. 2007. Pathophysiology of acute wound healing. Clinics in Dermatology 25:9-18.

Lin ZQ, Kondo T, Ishida Y, Takayasu T, Mukaida N. 2003. Essential involvement of il- 6 in the skin wound healing process as evidenced by delayed wound healing in il-6 deficient mice. Journal of Leukocyte Biology 73:713-721.

Lostapa IWFW, Wardhita AAGJ, Pemayun IGAGP, Sudimartini LM. 2016. Kecepatan kesembuhan luka insisi yang diberi amoksisilin dan asam mefenamat pada tikus putih. Buletin Veteriner Udayana 8(2):172-179.

Macleod AS, Mansbridge JN. 2015. The innate immune system in acute and chronic wound. WHS 5(2):65-78.

Naseem S, Iqbal R, Munir T. 2016. Role of interleukin-6 in immunity : a review. International Journal of Life-Science Scientific Research 4(2):268-274.

Nagaoka T, Kaburagi $Y$, Hamaguchi $Y$, Hasegawa $M$, Takehara K, Steeber DA, Tedder DF, Sato S. 2000. Delayed wound healing in the absence of intercellular adhesion molecule-1 or I-selectin expression. American Journal of Clinical Pathology 157(1):237-247. 
Seaton M, Hocking A, Gibran NS. 2015. Porcine models of cutaneous wound healing. ILAR Journal 56(1):127-138.

Sheta E, Elzomor S, Eltookhy O, Elkader NAA, Ahmed KA. 2014. Structural and functional renovation of urinary bladders after amniotic membrane implantation in dogs. IJVSM 2:57-66.

Thalib A. 2017. Pengaruh Pemberian Krim Topikal Ekstrak Buah Naga Merah (Hylocereus polyrhizus) pada Luka Akut terhadap Kadar Interleukin6 Fase Inflamasi pada Wistar. Tesis S2. Sekolah Pascasarjana, Universitas Hasanuddin. Makassar.
Theoret C. 2017. Chapter 1: Physiology of Wound Healing in Equine Wound Management. 3th Ed. John Wiley and Sons Inc. Iowa.

Tsai HC, Chang GRL, Fan HC, Yang HO, Huang LC, Wu SC, Chen CM. 2019. A mini-pig model for evaluating the efficacy of autologous platelet patches on induced acute full thickness wound healing. BMC Veterinary Reasearch 191(15):1-13.

Wilkinson JM, Treas LS, Barnett KL, Smith MH. 2016. Fundamentals of Nursing: Theory, Concept, and Application. 3rd Ed. Vol. 1. F.A.Davis. Philadelphia. 